\title{
Dispute Settlement Practices through the Religious Court's Mobile Court (Sidang Keliling)
}

\author{
Hazar Kusmayanti ${ }^{1}$, Sherly Ayuna Puteri ${ }^{2}$ \\ ${ }^{\text {I}}$ Faculty of Law, UniversitasPadjadjaran, Indonesia, Email: Hazar.kusmayanti@unpad.ac.id \\ ${ }^{2}$ Faculty of Law, UniversitasPadjadjaran, Indonesia, Email: Sherly.ayunaputeri@yahoo.com
}

\section{Article Info}

Keywords:

Mobile Court, Dispute Settlement, Religious Court.

How to cite:

Hazar Kusmayanti, Sherly Ayuna

Puteri, "Analyzing Patent

Information on Canning

Technology for Food to Enhance

Potential Industrial Development",

Fiat Justisia: Jurnal Ilmu Hukum

14, 3 (2020): 287-300.

DOI:

10.25041/fiatjustisia.v14no3.1708
This research is attempted to analyze the practices of mobile court and compare it with others. Based on the results of the study, the conclusions that can be obtained are that the implementation of the circuit court conducted at the Tasikmalaya District Religious Court has fulfilled several principles of civil procedural law, namely fast, simple and low cost. Among them when people who experience obstacles to come to the court office for reasons of distance, transportation and costs of the court come directly to the location, the bureaucracy is not complicated meaning that the implementation of the trial must be completed no later than 4 times the hearing, and the existence of an effective control system and various elements. Obstacles in the conduct of circuit courts include no standard guidelines for the holding of circuit courts, not all cases registered by residents are resolved in circuit courts, limited budgets, cases that have not been heard are all without prodeo, facilities and infrastructure, and not all religious courts hold circuit courts.

\section{A. Introduction}

The 4th Amendment of the 1945 Constitution, Article 24 paragraph (2) states that "The judicial power shall be implemented by a Supreme Court and judicial bodies underneath it in the form of public courts, religious courts, military courts, and state administrative courts, and by a Constitutional Court. ${ }^{1}$ Article 24 paragraph (2) of the 1945 Constitution implemented by Law No.

${ }^{1}$ E. L. Fakhriah, "Eksistensi Hakim Perdamaian Desa Dalam Penyelesaian Sengketa di Pengadilan Negeri," Jurnal Sosio Humaniora 18, No. 2 (2016). https://doi.org/10.24198/sosiohumaniora.v18i2.9942. 
48 of 2009 concerning Judicial Power stated that judicial bodies under the Supreme Court include judicial bodies in the public courts, religious courts, military courts and State Administrative Courts. The scopes of public courts are the District Courts, High Courts, and the Supreme Court. The scope of the religious court is the Religious Court, the Religious High Court, and the Supreme Court. The scope of the military court is the Military Court, the High Military Court, and the Supreme Military Court, namely the Supreme Court. The scopes of the State Administrative Court are the State Administrative Court, the High Administrative Court, and the Supreme Court. ${ }^{2}$

Religious Courts are legitimate State Courts, aside from being Special Courts that is Islamic Courts in Indonesia. The Religious Courts are authorized by the state legislation, to realize Islamic material law within the limits of its power. To implement its main tasks and functions then The Religious Courts apply for the Program in various laws and regulations, even the Procedural in unwritten law. ${ }^{3}$

After the issuance of Law Number 7 of 1989 which has been amended by Law Number 50 of 2009 concerning the Religious Courts, the Procedural Religious Courts law became clear and referred to one guideline. In practice, there are still many commoners who are afraid to deal with the law and also have no knowledge concerning legal issues, giving attorneys the power to resolve legal issues in the courts is the most common choice. Sometimes, those who litigate should inevitably find a lawyer and have to spend some certain amount of money for it whether they like it or not. It seems like finding a lawyer is the only way to settle a case in court. Then the community often assumes litigation in court is not one quick way to settle a case.

There are too many elusive formalities or complicated regulations, which allow various laws to arise and cause their reluctance or fear to go to court. The word quick points to the course of the courts, too many formalities are obstacles to the course of not only the hearing before the court but also the settlement of the minutes of investigation at the trial until the signing of the verdict by the judge and its implementation. Not infrequently a case is delayed for years due to the absence of the witnesses, or each of the parties asked for a retreat. Major of the case is continued by the heirs. The speed of the judicial path will increase the prestige and public trust to the court. The provision of the low cost to be borne by the people, and the high cost of cases causing the reluctance of the parties to submit rights claims to the court. ${ }^{4}$

This is in contrast to the principle of justice in resolving cases one of which must fulfil the principle of simple, fast and low cost. This principle is

\footnotetext{
${ }^{2}$ Roihan A Rasyid, HukumAcaraPeradilan Agama (Jakarta: Raja Grafindo Persada, 2006).

${ }^{3}$ Hazar Kusmayanti, Sherly Ayuna Puteri, "Implementasi Perma No. 1 Tahun 2015 terhadap Pelaksanaan Sidang Keliling,” Jurnal Adhaper 11, (2018).

${ }^{4}$ M. Salehand lilik Mulyadi, Bunga Rampai Hukum Acara Perdata Indonesia (Perspektif, Teoritis, Praktik dan Permasalahannya (Bandung: Alumni, 2012), 393.
} 
the principle of justice that applies in the country of Indonesia. This principle is stated in Article 2 paragraph (4) of Law Number 48 of 2009 concerning Judicial Power. The principle was at first regulated in Article 4 paragraph (2) of Law No. 14 of 1970 which explained in point 8, namely "the provision that the judiciary is conducted in such simple, fast and low-cost way must still be held firmly which reflected in the law on criminal procedural law and civil procedural law that contain much simpler rules about investigation and verification".

The development of a country is often accompanied by various problems surrounding it, such as inequalities resulting from uneven development followed by lack of access to justice due to economic problems and low levels of public education ${ }^{5}$. Based on the above statement, the Supreme Court issued Letter of the Supreme Court (SEMA) No. 10 of 2010 concerning Guidelines in Providing Legal Aid. The mobile court is one of the work programs of the Religious Courts in the last few years, which aims to provide access for justice seekers. This goal is in line with the agenda of the Supreme Court and the Director-General of Religious Courts Body to create conditions where people (justice seekers) can easily access and channel his rights to obtain justice from the court, with the slogan justice for all. The mobile court is a trial which is held outside the court building aimed for people who experience obstacles to come to the courthouse for reasons of distance, transportation and costs. ${ }^{6}$

The mobile court is very helpful for the community in fighting for essential justice in the situations when people need law enforcement to solve cases that require a decision to strengthen their legal strength but are hindered by obstacles that may not be able to be reached by them. The following are the benefits obtained by the existence of mobile court process: the location of the trial is closer to the place of residence that filed the case, fewer transportation costs, and time efficiency. ${ }^{7}$

Mobile Court is a trial which is conducted outside the court, located within the jurisdiction of the court and functions as a place of permanent trial. The mobile court also helps those who are geographically difficult to reach the Court. According to researchers, this is a good solution, due to some cases in society that can only be resolved through the Court. In the new regulation regarding the mobile court, Supreme Court Regulation (PERMA) No.1 of 2015 concerning Integrated Services for the District Court and Religious

\footnotetext{
5 Thalis Noor Cahyadi, "Efektifitas Pos Bantuan Hukum di Pengadilan (Studi Pada Posbakum Pengadilan Agama Sleman Tahun 2011-2012)," Jurnal Rechts Vinding 2, No. 1 (2013). March 24 , 2018. Available

7 M Zaky Hidayatullah, "Efektivitas Sidang Keliling Pengadilan Agama Sampit Dalam Penyelesaian Perkara Hukum Keluarga," Jurnal Studi Agama dan Masyarakat 12, No. 2 (2016): 217. https://doi.org/10.23971/jsam.v12i2.480.
} 
Courts / Syar'iyah Court in the context of the issuance of marriage certificates, marriage books, and marriage certificates. The existence of the Supreme Court Regulation (PERMA) No.1 Year 2015 can facilitate justice seekers who are embarrassed and reluctant to deal with the difficult and complicated legal system since a long and complicated system opens a gap for corruption. For this reason, many poor groups of people are unreachable by law. Seeing this problem, the Religious Courts also made a breakthrough to reach out to the poor and marginalized groups who were entangled in family law cases. The breakthrough is done through the mobile court and providing free services through legal aid posts.

The mobile court which is conducted by the Court, in fact, experiences many obstacles in practice, such as:

1. There is a normative difference between the procedural law and case administration with the budget system in the Budget Implementation Entry List;

2. There is a gap between the pagu in the Budget Implementation Entry List and the number of justice seekers who need the services of the mobile court that caused the inability to reach other justice seekers;

3. Limited number of mobile court team members due to the very limited budget system in the Budget Implementation Entry List.

The purpose of conducting the mobile court, as described above is to make it easier for people in seeking justice. ${ }^{8}$ For example, if the litigant lives far from the court and the access is difficult, then the mobile court is the solution to the problem. After doing an observation in the Religious Court of Tasikmalaya, researchers obtained a problem in practice in reality which is his existence of a gap between the practices of conducting a mobile court with the theory of civil procedure law, one of which is the principles of the Civil Procedural law. The researchers found that due to the place where the court was held always moved, more and more people in the countryside were easily divorced by one session on the first day so that the divorce rate in Tasikmalaya was the highest in West Java. The Religious Court of Tasikmalaya District could conduct the trials for more than 45 , even up to 100 more cases a day. In fact, for now the court is very short of human resources both in terms of judges and court employees compared to other courts.

Based on the description above, the author is interested in researching the implementation of the mobile court conducted by the Religious Court of Tasikmalaya District considering that in the case of the technical rules of mobile court proceedings are not regulated in SK KMA No.26 of 2012 or SEMA No. 10 of 2010. Whether the implementation is on target and really benefited the community, who experienced obstacles in the field of transportation and lay in the field of law. And indeed, in this case, there is a

${ }^{8}$ Ibid. 
decision by the Religious Court itself in a state of lack of human resources to decide cases in distant radius from the Religious Court. So this research is entitled "Mobile Court based on the Civil Procedure Law and Supreme Court Regulation No. 1 of 2015". As for the problem statement in this study is how the implementation of the mobile court related to the principles and principles of civil procedural law is?

Based on the description in the identification of the problems mentioned above, to analyze the implementation of the court session in the religious court is in accordance with the principle of fast, simple and low-cost civil procedural law, as well as obstacles of the proceedings of mobile religious courts in resolving civil disputes in practice. The approach method in this study is normative empirical and also was conducted by collecting secondary data (primary, secondary, tertiary) legal materials. Primary legal materials, namely binding legal materials in the form of laws and regulations, for example, Law No. 48 of 2009 concerning Judicial Power, Het Herziene Indonesisch Reglement or HIR, Law Number 7 of 1989 as amended by Act No. 3 of 2006 and Law Number 50 of 2009 concerning Religious Courts and Supreme Court Regulation (Perma) No.1 of 2015 Regarding integrated services surrounding the court and religious court / syar'iyah court in the context of the issuance of marriage certificates, marriage books, and birth certificates.

\section{B. Discussion}

\section{Mobile court practice in the Tasikmalaya District Religious Court based on the principle of civil procedural law}

The settlement of cases in mobile courts is based on simple, fast, and lowcost principles. ${ }^{9}$ These principles are everybody's ideal court. If it can be implemented properly, it will make the Court as the choice for justice seekers, simple in the procedure of filing the lawsuit, fast in the trial process, proving up to the verdict and without an expensive fee (in accordance with court fee provisions). One of the ways to create good service and justice for every level of society is the establishment of a Mobile Court in the Religious Courts by the Supreme Court of the Republic of Indonesia. The establishment of this mobile court is expected to achieve "the principle of fast, simple and lowcost" which means the judiciary must be conducted in fast, simple and lowcost manner as well as free, honest and impartial must be applied consistently in all levels of justice.

Article 4 paragraph (2) of Law Number 48 of 2009 concerning Judicial Power stated, the simple principle means fast, and low cost means a judge in trying a case must try as much as possible to settle a case in such a short time.

\footnotetext{
${ }^{9}$ M. Yahya Harahap, Kedudukan Kewenangan dan Acara Peradilan Agama, (Jakarta: Sinar Grafika, 2001), 56.
} 
The fewer and more straightforward the formalities required or needed in court proceedings, the better. There are too many understandable formalities causing various interpretations, not guaranteeing the existence of legal certainty and lead to reluctance or fear of proceedings before a light court. ${ }^{10}$

Based on interviews conducted by the researchers with the Young Registrar of the Religious Courts of Tasikmalaya District, the cases in mobile court were mostly divorce cases, and the parties usually did not continue the case at the Appeal level. The accumulation of cases in the high court can be overcome because the parties do not file an appeal, and the case can be completed at the first level. The budget in implementing mobile court session is obtained from Grants and the budget implementation document prepared by Budget Users/Budget User Proxies. If the Budget Implementation Entry List for the implementation of the mobile court has been depleted so that there is no more mobile court, then the examination is continued in the court building where the court is domiciled, but this rarely happens. ${ }^{11}$

Based on the interview that the researchers conducted with one of the teams of the mobile court apparatus which is the young registrar in the Religious Court of Tasikmalaya Regency, the legal basis they referred to is Supreme Court Regulation (PERMA) Number 1 of 2015. In the process of the mobile court, the Supreme Court intends to order the lower ranks to provide excellent service in real terms in the community in each of the Religious Courts. "In terms of a request to change a name, the name change is made easy. We made this in order to not to difficult people", said the Registrar of the Religious Court of Tasikmalaya District. He also said that according to the regulations, there were indeed costs to be paid for residents who wanted to make some repairs on important letters. ${ }^{12}$ However, there is a cooperation with the government in Tasikmalaya Regency that the costs to be paid by the poor citizens who propose to repair important letters are zero or free. Purnomo added that in the future residents who want to repair important letters must include a not capable certificate from the local village.

However, for residents who can pay according to the provisions and the costs of the down payment is around 400.000 IDR. He stated that this policy was a breakthrough. The procedure to repair various important letters becomes faster; the time needed is also shorter. By the rules, the time needed is about one week, but with this program, it takes about five minutes. ${ }^{13}$

Based on the interviews the researchers conducted with one of the registrar of Tasikmalaya Court, the background of the establishment of the mobile court in Religious Court is so that the remote community also received

\footnotetext{
${ }^{10}$ Sudikno Mertokusumo, Hukum Acara Perdata Indonesia, (Yogyakarta: Liberty, 1998), 36.

${ }^{11}$ Interview result with the Young Registrar of the Religious Court of Tasikmalaya Mr. Purnomo, on August 28, 2017 at the Tasikmalaya Religious Court

12 Ibid.

${ }^{13}$ Ibid.
} 
legal services from the Religious Court of Sampit since in Tasikmalaya District there had been regional expansion. There were still many districts not have a Religious Court. The registrar emphasized that it was very influential in setting the background for the mobile court at the Religious Court of Tasikmalaya District because Letter of the Supreme Court (SEMA) No.10 of 2010 has regulated this matter as one of the legal assistance provided by the religious court to the community and also due to the budget implementation document funds given by the Government of Tasikmalaya Regency as a supporter of the background idea of the implementation of the mobile court at the Religious Court of Tasikmalaya. The Religious Court of Tasikmalaya usually conducts a mobile court at the Village Office Meeting Hall. The team in charge of the assignment letter consisted of 14 people, departed from the Tasikmalaya Religious Court office at 08.00 in the morning, and arrived at the Village Office at around 09.00. In addition to the Chairperson and Deputy of the Religious Court of Tasikmalaya, 4-5 were judges in charge, substitute registrar, substitute bailiffs, bailiff Nasarudin and a driver. The local village head welcomed the team along with all the village personnel and litigant parties who were also present. Without further ado, the trial began right away.

The cases that were tried mostly were cases of divorce and Istbat Nikah cases, which consisted of at least 11 cases which were also decided on that same day. After all the cases were heard, the briefing was carried out by the Chief of the Religious Court of Tasikmalaya District who was also attended by the Head of the Village and the entire village. During the briefing, the parties were given a copy of the decision as a result of the trial.

The parties who filed the case wanted the case to be completed quickly. This is in line with the principle of justice which outlines that the judiciary is conducted in a simple, fast and low-cost manner, so that the Mobile Court of the Religious Court of Tasikmalaya District and Religious Court of Bale Bandung, has been going on for several years. The mobile court continues, although there are no guidelines posted from the Supreme Court of the Republic of Indonesia today. The court apparatus seeks to open access to justice for people who live far from the court to facilitate the reach of services for the community. Justice does not only belong to people who have money since long distances must not obstruct the right of citizens to get justice.

The Religious Court of Tasikmalaya District appointed two Judges to try the cases, the first assembly on Tuesday and the second one on Thursday. Each Assembly conducts a trial twice in one month, it means the trial is conducted once every two weeks, and therefore there are four sessions in one month. According to Article 6 of Regulation No. 1 of 2015, the Court can conduct hearings outside the Courthouse, especially for cases where proof is easy or straightforward. So, the mobile court is one form of the trial outside the Courthouse, specifically for cases where the proof is easy or simple. This can speed up the trial process until the verdict is reached. 


\section{Determined Light Costs at the Court Proceedings}

That means to be affordable for all people. Expensive costs mostly caused interested parties to be reluctant in filing rights claims to the court. Low cost means an affordable fee for the community. However, simple, fast, and lowcost principles do not exclude precision and accuracy in seeking truth and or the fear of proceedings before a light court. ${ }^{14}$ There is no definite budget allocation for the mobile court because it depends on various factors such as distance and travel time to the location of the mobile court. ${ }^{15}$ Based on the description above regarding the steps of court proceedings in a circuit court, it seems that several things are different from the proceedings regulated in the HIR, the simple legal principles in the court session are as follows:

a. Do not take the bureaucratic path that is convoluted, and uses a lot of formalities. The parties only come to the court (without the need to be accompanied by a legal representative) at the court, sub-district office, Religious Affairs Office or KUA office, or public facilities that are easily accessible by people who live far from the court office.

b. In the process of filing a lawsuit, while in the implementation of the trial, the applicant/plaintiff must bring at least two witnesses who are aware of the problem. Therefore, there is no formality problem because there are many lawsuits in the travelling court which were aborted before being examined by the court as well as ordinary trials

c. There is an effective control system of various elements, such as commissions or monitoring institutions, community organizations and mechanisms for actively involving community participation.

The principle of further proceedings is that it is swift regarding the course of the examination up to the implementation of the decision in the implementation of the circuit court, which can be described as follows:

a. In a circuit court session, it is not the case that the examination of the case takes place protracted using complicated procedures so that it is not finished and stops in the middle of the examination because the trial is conducted once in one day of the trial.

b. Factors that slow down the trial process can be eliminated, for example, parties who have no good intentions, lack of witnesses and difficult evidence, and officers of unprofessional judicial institutions such as judges, lawyers and court officials. Justice seekers who file lawsuits or petitions to the court generally prefer the case to be quickly decided, not having to undergo a review of the case lasting years even though the verdict is ultimately favourable.

${ }^{14}$ Sudikno, Op.Cit., 36.

${ }^{15}$ Religion Court Relief Budget, October 1, 2018. www.pa-kandangan.go.id. 
c. The legal assistance factor also sometimes makes the process of hearing a trial take a long time. Article $123 \mathrm{HIR}$ and Article 142 for the parties to be assisted or represented by their proxies if they wish. People who are ignorant of the law will be confused and unable to litigate in court to bring up legal incidents. This will be used by some unscrupulous lawyers to deceive their clients into extending the case by asking for a modest case fee. With the decision and its implementation in the State of Indonesia, it can still run quickly and thoroughly in time.

d. Regarding the examination of the HIR case, primarily it is hoped that the examination will be completed at the first hearing, as stated in Article 159 paragraph 1: "if a case can be settled on the first day ..." The article shows that the HIR requires quick resolution, and generally in reality except for declaratory cases, no simple civil matters can be resolved in a trial. In the implementation of the circuit court session, there is no longer an examination process that impedes the proceedings of the trial at the time of the adjournment process. The adjournment process occurs at the request of the parties or ex officio by the judge. In practice, what happened at the trial judge was less strict if the parties or their attorneys submitted the request for adjournment.

The last principle is the low cost. The researcher found the connection with the holding of the mobile court as follows:

a. For those who are unable to pay, they can propose a free trial or litigation, and this is "really" applied, for example, the Itsbat Nikah in the form of prodeo (free to pay for litigation fees) is done jointly between religious courts. In ordinary court practice people who can not afford can also be full or free of charge, there are costs that they have to pay such as postal fees, stamp duty, photocopy fees which amount is not small and others. Now, what is only paid at the circuit court pays in advance the cost of the case for a "just" trial, not followed by other costs.

b. There is no demand to pay the case fee. In principle, for a case to be charged a case fee, this is regulated in Article 4 paragraph (2), Article 5 paragraph (2) of Law No. 48 of 2009 concerning Judicial Power. These court fees include court fees and stamp duty, call fees, notification of parties, witness fees, experts and interpreters as well as their oath fees, local examination fees and other judges' actions, the salary of officials who are told to make summons, salaries to be paid to court clerks or other officials for carrying out the judge's decision (Article 182 HIR jo 194 Rbg).

c. For remote communities who have difficulty with access to transportation and the distance travelled to the courthouse is no longer a problem. The purpose of a circuit court conducted by a religious court is to serve the community in areas far from the courthouse. 


\section{Resistance to Procedure in the Practice of Mobile Courts in Religious Courts in settlement of Civil Disputes}

Being set up from the Religious Courts is the modernization of the judiciary religion in the context of strengthening the justice structure in Indonesia. Besides the main task of the religious court is to regulate the operation of the court ${ }^{16}$, there will be provisions governing territory procedural powers, such as examining and judging people who are Muslim, reconcile and or prosecute, in certain case fields. ${ }^{17}$ The holding of a trial session abroad has been programmed for decades as in Malaysia known as the "Mobile Court Chamber". It turns out that the legal and justice program for justice seekers is the same as the Religious Courts activities program in Indonesia, namely the "Mobile Court Session Program" which began in five 2007. The barriers to proceedings in the practice of the mobile court of the Religious Courts (PA Tasikmalaya case study) are as follows:

\section{a. There is no standard guideline for conducting mobile courts}

The guidelines for the implementation of the mobile court have not yet been compiled, making the mobile court session the flagship program and mainstay of the religious court not yet orderly and uniformly with its reporting. The following are various guidelines that have existed in various internal regulations, namely as follows:

1) The Master Plan for the Development of Religious Courts 2000-2009 published by the Ministry of Religion of the Republic of Indonesia cq. Directorate General of Islamic Institutional Development (Binbaga Islam) up. The Directorate of Islamic Religious Courts Development (Ditbinbapera) in the year 2000, contained data and strategic plans on the "Traveling Session".

2) The book of the Religious Courts Profile 2005 issued by the Directorate General of Badilag MARI, that in 2004 there were 75 Religious Courts and the Syar'iyah Court which held a circuit court with a total of 208 trial places, with a total of cases being tried through the "Mobile Court" totalling 8,039 cases.

3) Guidance Session for Religious Courts in 1998-1999, published by the Ministry of Religion of the Republic of Indonesia cq. Directorate General of Islamic Institutional Development (Binbaga Islam) up. The Directorate of Islamic Religious Courts Development (Ditbinbapera) on 1 May 1998 (at that time held by Drs. H. Syamsuhadi, SH) whose contents included:

\footnotetext{
${ }^{16}$ H.A. Khisni, "Peradilan Agama Sebagai Peradilan Keluarga Serta Perkembangan Studi Hukum Islam di Indonesia," Jurnal Hukum Universitas Sultan Agung 25, 1 (2011): 492.

17 Muhammad Latief Fauzi, "Efektivitas Sidang Keliling (Studi di Pengadilan Agama Wonogiri)," Jurnal Ad-Dalah 14, 2 (2017).
} 
understanding, scope, objectives, legal basis, and procedures for organizing a "Mobile Session" to coordinate strategy with local agencies.

\section{b. The trial session is still relatively new}

In fact, there are still many things that need to be improved, including not all cases registered by citizens of Cipatujah are settled in a circuit court. Cases that contain material disputes continue to be heard in PA Tasikmalaya. The reason, the process of settling these types of civil cases is more complicated.

\section{c. Due to budget constraints, the travelling session held by religious court Tasikmalaya district only handles non-prodeo cases}

Many people are asking for litigations for free, but they must be willing to stand in line to wait their turn. "Because the allocation for Prodeo cases in the 2010 budget year is indeed limited. Hopefully, 2011 will increase", stated the chief Tasikmalaya Mahmud Religious Court.

\section{d. The public is still layman if there is a mobile court the apparatus have known this term of the Religious Courts (in particular)}

The practice of the circuit court has existed, long before the one-stop religious court under the Indonesian Supreme Court. Even continues to this day. However, its implementation is by utilizing government buildings / other agencies, such as village halls, sub-districts offices, KUA offices, or public facilities that are easily accessible to people who live far from the Court Office. PA Tasikmalaya's strong desire to provide public services through mobile courts should be appreciated, even appreciated PA Tasikmalaya won first prize for the excellent service of its travelling congregation. But there are various obstacles encountered in the field, especially regarding the place of the trial which is still borrowing the room at another institution. The Tasikmalaya and Badilag religious courts continue to strive to ensure that the itinerant meeting places do not stay in people's offices. It's better to have your own permanent building.

\section{Conclusion}

The implementation of the mobile court conducted in the West Java Religious High Court, especially in the Religious Court of Tasikmalaya has fulfilled the principle of civil procedural law, namely fast, simple and low cost. The mobile court proved to be able to open more broadly access to justice to the community. Among other things, when people experienced obstacles for reasons of distance, transportation and costs, the mobile court which comes directly to the location provides a much simpler examination, in this case, the implementation of the trial must be completed at the maximum in four sessions. Although the examination is conducted in faster and simpler ways, the existence of an effective control system from various elements, such as 
commissions or monitoring bodies, community organizations and mechanisms for community participation is actively able to maintain the quality of court proceedings. Some of the obstacles in the implementation of the mobile courts are there is no standard guideline for the implementation of the mobile court, not all types of cases registered by citizens could be examined in the mobile court, limited budget, not all cases were devised, facilities and infrastructures for carrying out the assembly and not all religious courts conducting mobile courts.

\section{References}

Ali, Daud Muhammad. Hukum Islam Pengantar Ilmu Hukum dan Tata Hukum Indonesia. Jakarta: Raja Grafindo Persada, 2000.

Anggaran Bantuan Pengadilan Agama, October 1, 2018. www.pakandangan.go.id.

Cahyadi, Thalis Noor. "Efektifitas Pos Bantuan Hukum Di Pengadilan (Studi Pada Posbakum Pengadilan Agama Sleman Tahun 2011-2012).” Jurnal Rechts Vinding 2, No. 1 (2013).

Fakhriah, E. L. "Eksistensi Hakim Perdamaian Desa Dalam Penyelesaian Sengketa di Pengadilan Negeri." Jurnal Sosio Humaniora 18, No. 2 (2016). https://doi.org/10.24198/sosiohumaniora.v18i2.9942.

Harahap, Krisna. Hukum Acara Perdata. Bandung: Grafiti Budi Utami, 2007. Hazar Kusmayanti, Sherly Ayuna Puteri. "Implementasi Perma No. 1 Tahun 2015 terhadap Pelaksanaan Sidang Keliling." Jurnal Adhaper 11, (2018). Het Herziene Indonesisch Reglement or HIR.

Hidayatullah, M. Zaky. "Efektivitas Sidang Keliling Pengadilan Agama Sampit Dalam Penyelesaian Perkara Hukum Keluarga." Jurnal Studi Agama dan Masyarakat 12, No. 2 (2017). https://doi.org/10.23971/jsam.v12i2.480.

Kansil, C.S.T. Pengantar Ilmu Hukum dan Tata Hukum Indonesia. Jakarta: Balai Pustaka, 1998.

Khisni, H. A. "Peradilan Agama Sebagai Peradilan Keluarga Serta Perkembangan Studi Hukum Islam di Indonesia." Jurnal Hukum Universitas Sultan Agung 25, No. 1 (2011).

Kurniati, N. "Mediasi-Arbitrase Untuk Penyelesaian Sengketa Tanah." Jurnal $\begin{array}{lllll}\text { Sosio Humaniora } & \text { 18, No. } & \end{array}$ https://doi.org/10.24198/sosiohumaniora.v18i3.10008.

Law No. 48 on 2009 of Judicial Power.

Law No. 7 on1989 as amended by Law No. 3/2006 and Law No. 50/2009 of Religious Courts.

Memberi Keadilan Bagi Pencari Keadilan, March 24, 2018. https://www.pekka.or.id/.../Providing\%29Justice_Indonesian.pdf. 
Muhammad Latief Fauzi,(2017),"Efektivitas Sidang Keliling (Studi di Pengadilan Agama Wonogiri)", Jurnal Ad-Dalah 14, No. 2, https://doi.org/10.24042/adalah.v14i2.2057.

Mujahidin, Ahmad. Pembaharuan Hukum Acara Peradilan Agama. Jakarta: Ghalia Indonesia, 2012.

Perma No.1 on 2015 of integrated services of Sidang Keliling the district and religious courts / syar'iyah courts in the context of the issuance of marriage certificates, marriage books, and birth certificates.

Saleh, M., Mulyadi Lilik. Bunga Rampai Hukum Acara Perdata Indonesia (Perspektif, Teoritis, Praktik dan Permasalahannya). Bandung: Alumni, 2012.

Siding Keliling Prodeo, June 2018. http://www.pta-bandung.go.id/sidangkeliling-prodeo-posbakum.html.

Soebekti. Hukum Acara Perdata. Jakarta: Bina Cipta, 1977.

Soekamto, Soerjono. Pengantar Penelitian Hukum. Jakarta: UI Press, 2007.

Soerjono Soekamto dan Sri Mamudji. Penelitian Hukum Normatif. Jakarta: Rajagrafindo Persada, 2018.

Sudikno. Hukum Acara Perdata Indonesia. Yogyakarta: Liberty, 2013.

Sutantio, Retnowulan, Iskandar Oeripkartawinata. Hukum Acara Perdata dalam Teori dan Praktek. Bandung: Mandar Maju, 1997. 
